\title{
Perspective \\ Metabolic Shifts as the Hallmark of Most Common Diseases: The Quest for the Underlying Unity
}

\author{
Laurent Schwartz $^{1, *}$, Marc Henry ${ }^{2}$, Khalid O. Alfarouk ${ }^{3,4}{ }^{\oplus}$, Stephan J. Reshkin ${ }^{5}\left(\mathbb{D}\right.$ and Miroslav Radman ${ }^{6}$ \\ 1 Assistance Publique des Hôpitaux de Paris, 75004 Paris, France \\ 2 Laboratoire de Chimie Moléculaire de l'Etat Solide, UMR 7140 UDS-CNRS, University of Strasbourg, \\ 4 rue Blaise Pascal, F-67000 Strasbourg, France; henry@unistra.fr \\ 3 Department of Pharmacology, College of Pharmacy, Zamzam University College, Khartoum 11123, Sudan; \\ Alfarouk@Hala-Alfarouk.org \\ 4 Department of EMS, Al-Ghad International College for Applied Medical Sciences, \\ Al-Madinah Al-Munwarah 42316, Saudi Arabia \\ 5 Department of Bioscience, Biotechnology and Biopharmaceutics, University of Bari, 70126 Bari, Italy; \\ stephanjoel.reshkin@uniba.it \\ 6 Mediterranean Institute for Life Sciences (MedILS), 21000 Split, Croatia; miroslav.radman@medils.hr \\ * Correspondence: dr.Laurentschwartz@gmail.com
}

check for updates

Citation: Schwartz, L.; Henry, M.; Alfarouk, K.O.; Reshkin, S.J.; Radman, M. Metabolic Shifts as the Hallmark of Most Common Diseases: The Quest for the Underlying Unity. Int. J. Mol. Sci. 2021, 22, 3972.

https://doi.org/10.3390/ijms22083972

Academic Editor: Peter Bross

Received: 7 March 2021

Accepted: 3 April 2021

Published: 12 April 2021

Publisher's Note: MDPI stays neutral with regard to jurisdictional claims in published maps and institutional affiliations.

Copyright: (c) 2021 by the authors. Licensee MDPI, Basel, Switzerland. This article is an open access article distributed under the terms and conditions of the Creative Commons Attribution (CC BY) license (https:// creativecommons.org/licenses/by/ $4.0 /)$.

\begin{abstract}
A hyper-specialization characterizes modern medicine with the consequence of classifying the various diseases of the body into unrelated categories. Such a broad diversification of medicine goes in the opposite direction of physics, which eagerly looks for unification. We argue that unification should also apply to medicine. In accordance with the second principle of thermodynamics, the cell must release its entropy either in the form of heat (catabolism) or biomass (anabolism). There is a decreased flow of entropy outside the body due to an age-related reduction in mitochondrial entropy yield resulting in increased release of entropy in the form of biomass. This shift toward anabolism has been known in oncology as Warburg-effect. The shift toward anabolism has been reported in most diseases. This quest for a single framework is reinforced by the fact that inflammation (also called the immune response) is involved in nearly every disease. This strongly suggests that despite their apparent disparity, there is an underlying unity in the diseases. This also offers guidelines for the repurposing of old drugs.
\end{abstract}

Keywords: Alzheimer; psychiatry; cancer; entropy; pHi; mitochondria; lactic acid; methylene blue; a paradigm shift

\section{Introduction}

From a thermodynamic standpoint, cell viability feeds on low entropy molecules such as glucose to release higher entropy molecules such as $\mathrm{CO}_{2}$ and ATP [1]. Low entropy compounds are absorbed by the cells and degraded into higher entropy either in the form of heat (catabolism) or biomass (anabolism), complying with the second law of thermodynamics [2-4].

Metabolism is the ensemble of life-sustaining chemical transformations within the cells. Indeed, cell metabolism is not solely the sum of all the chemical reactions and dynamic exchanges between a cell and its microenvironment, but it is primarily the core executing, performing, and operating life continuum. Comparative analyses of genes and genomes from organisms belonging to Eukarya reveal that, during evolution, there have been limited changes, slight evolutionary flexibility in the evolution of cellular metabolism (amino acids, carbohydrates, and lipid metabolism), to support basic functions of life [5].

As an open system, a cell selectively uptakes various compounds from its microenvironment, first deconstructing simple sugars modifying their sub-units along anabolic metabolic pathways, for then building up a set of macromolecules having crucial functions 
such as DNA, proteins, and enzymes, lipids, etc., enabling to maintain metabolic activity. The capture of free energy from molecular bond rearrangement of carbon sources in catabolic reactions by means of enzymes coupled to energy currency (ATP/ADP) and redox cofactors $\left(\mathrm{NADH} / \mathrm{NAD}^{+}\right.$and $\mathrm{NADPH} / \mathrm{NADP}^{+}$) powers anabolic reactions that sustain function [4]. These enzyme-catalyzed reactions allow organisms to grow and reproduce, maintain their structures, and respond to their environments.

In most cells, dingle glucose catabolism (e.g., glycolysis pathway) results in two ATP molecules (by recycling two ADP molecules) while converting one mole of glucose to two moles of pyruvate. However, in respiring cells, up to 34 ATP molecules are obtained, and the 2 ATP from glycolysis. Cell respiration is an oxidative phosphorylation (OXPHOS) process. Cells thus convert low entropy glucose by means of an electron-proton transfer process to high entropy ATP from ADP [1]. The energy of electron flow is stored in the form of chemical-free energy of the phosphate-phosphate bond in ATP molecule, which is then used to execute mechanical, osmotic, and biosynthetic work supporting cell functions, viability, and growth [6]. OXPHOS occurs within mitochondria; electrical charges are transferred to oxygen via redox reactions, and protons are pumped from the matrix across the mitochondrial inner membrane. ATP is synthesized when protons return to the mitochondrial matrix down their electrochemical gradient. The rate of entropy production in OXPHOS is determined by the bio-membrane conductance and the electromotive potential across the mitochondrial membrane [4].

\section{Cells Proliferate under Redox Conditions and Differentiate from Oxidation}

The mitochondrion seems to be more than just an efficient power plant for ATP turnover [7,8]. Mitochondria are at the core of eukaryotic cell metabolism and cell differentiation [1]. They also control the release of entropy in the form of heat.

Differentiated cells have an increased mitochondrial activity [7-9], resulting in the release of entropy in the form of thermal photons. Maturation of the mitochondrial network, as well as increased transcription of mtDNA, is observed during the differentiation of hESCs into cardiomyocytes [10], in differentiating hESCs [11], in osteogenic adipogenic and hepatogenic differentiation [12], or leukemia cell differentiation [13]. T-cell maturation involves the progression from anaerobic glycolysis to oxidative phosphorylation [14,15]. Transplantation of energy-producing mitochondria results in cell differentiation [16,17].

Differentiated cells have a basal oxidative metabolism. Pyruvate is converted from glucose and degraded by the efficient TCA cycle $[18,19]$. The oxidative phosphorylation of acetyl-CoA into mitochondria yields large amounts of entropy-rich ATP and releases carbon dioxide and water as waste products.

The opposite occurs in proliferative cells. The carbon flux is rewired to biomass synthesis and cell growth. Glycolysis is then shunted to the pentose phosphate pathway (PPP), generating nucleic acid precursors for DNA replication [18-20]. Poorly differentiated cells release their entropy in the form of biomass [1]. Undifferentiated cells have lower mitochondrial activity resulting in alkaline $\mathrm{pH}$, a lower transmembrane potential, and faster cell division [21].

Cells oscillate between two modes of entropy production. Differentiated cells release entropy in the form of heat. They have high ATP production, increased transmembrane potential, increased ionic concentration, intracellular acidic $\mathrm{pH}$, and higher water activity. On the other hand, proliferative cells have decreased ATP synthesis, diluted ionic content, low transmembrane potential, alkaline $\mathrm{pH}$ [7]. They release most of their entropy in the form of biomass.

\section{Metabolic Shifts in a Broad Spectrum of Diseases}

Anabolism and catabolism are not on/off phenomena. During adulthood, respiration is predominant [22]. Childhood and aging are more anabolic than adulthood. In childhood, anabolism results mostly in growth. In aging, anabolism results in age-related diseases such as cancer and Alzheimer's disease. 
Cells in early childhood experience a high proliferation rate resulting in cell multiplication and steady growth. Growth lasts up to puberty. Body growth is fast (about $20 \mathrm{~cm}$ per year) during early childhood and then slows down. A peak in growth is followed by growth cessation in puberty [23]. Growth stops when the hormones increase muscle strength resulting in increased mechanical pressure on the chondrocytes. Because of increased physical constraints, chondrocytes stop proliferating and differentiate into bone cells [23].

During aging, there is a shift toward anabolism. The reason for the shift toward anabolism is a decrease in mitochondrial function [17]. Age-related impairment in respiratory enzymes decreases ATP synthesis and enhances reactive oxygen species (ROS) production by increased electron leakage in the respiratory chain. When exposed to high ROS, proteins and nucleic acids are susceptible to oxidative damage, leading to an increased mtDNA mutation rate [24]. Aging is also associated with declines in the capacity of various cell types, including neurons, to respond to metabolic stress due to impairment of mitochondrial function $[24,25]$.

This shift toward anabolism was first described by the Nobel Prize winner Otto Warburg (1883-1970) in the 1920s. The Warburg effect is a modified cellular metabolism based on aerobic fermentation, which tends to favor anaerobic glycolysis rather than oxidative phosphorylation, even in the presence of oxygen. The Warburg effect results in the release of lactic acid in the extracellular space, the concomitant activation of the Pentose Phosphate Pathway, and anabolism [20].

The Warburg effect was first described in cancer, where it results in the synthesis of new proliferating cells [26]. The Warburg effect has been described in Alzheimer's and Parkinson's diseases [24,27].

Metabolic shifts are not limited to age-related diseases. An example is an anxiety. Catecholamines induce decreased mitochondrial activity resulting in the secretion of lactate [28,29]. In 1967, Pitts and McClure suggested that all anxiety symptoms are caused by a raised blood and body fluids lactate level [30]. Hollander has confirmed their work [31, 32]. Since then, Sajdyk demonstrated that the infusion of lactate results in anxiety in rats. Lactate infusion is associated with significant regional blood flow changes in panicking patients but not in the non-panicking patients [33].

The shift toward lactate synthesis has been demonstrated in a large spectrum of psychiatric diseases. There is an increased concentration of lactate $[34,35]$ in the sera of patients with autism spectrum disorders. MRI analysis confirmed the increased concentration of lactate in the brain of autistic patients [36]. There were increased cerebrospinal fluid (CSF) lactate concentrations in patients with bipolar disorder and schizophrenia [37]. In 1956, Altshule showed that abnormally large amounts of lactic acid accumulate in the blood after administering glucose in patients with schizophrenic or manic-depressive psychoses [29], confirming the metabolic shifts. The metabolic shift results from an alteration of complex IV of the mitochondria [38]. In autism, such an alteration of the complex IV has been reported [39]. There is a decreased activity of complex IV in schizophrenia [40] and depression [41].

Lactic acid is both the consequence of the metabolic shift and part of the reason for the diseases. Neurons feed on lactate released by glial cells [27]. The increased secretion of lactate by glial cells results in increased uptake by neurons and intracellular acidosis [27]. A fall in pHi decreases neuronal activity [42]. This is in line with neurons' exposition to increased lactic acid concentration that results in swelling and apoptosis [43]. The acidic intracellular $\mathrm{pH}$ has another significant metabolic consequence: a decreased uptake of glucose [27]. PET scan examination with the [18F]-fluorodeoxyglucose of the brain of psychiatric patients shows a decreased uptake of glucose in the cortex [44].

\section{Inflammation in a Broad Spectrum of Diseases}

Inflammation is part of the complex biological response of body tissues to harmful stimuli, such as pathogens, damaged cells, or irritants. It is a protective response involving 
immune cells, blood vessels, and molecular mediators. The function of inflammation is to eliminate the initial cause of cell injury, clear out necrotic cells and tissues damaged by the original insult and the inflammatory process, and initiate tissue repair. The four classical signs of inflammation are heat, pain, redness, swelling (calor, dolor, rubor, tumor).

At the onset of an infection, burn, or other injuries, these immune programs undergo activation and release inflammatory mediators responsible for the clinical signs of inflammation. Vasodilation and its resulting increased blood flow cause redness (rubor) and increased heat (calor). Increased permeability of the blood vessels results in a leakage of plasma proteins and edema, which manifests itself as swelling (tumor). The mediator molecules also alter the blood vessels to permit the extravasation of leukocytes into the tissue.

There is an inflammatory component in most, if not all, chronic diseases (Table 1). In autism spectrum disorder (ASD), postmortem microscopic analysis points toward an inflammatory disease linked to the blood-brain barrier's disruption [45]. There is also evidence of inflammation close to the neuron and the microglia with mast cells proliferation [46]. Analysis of the brain tissue confirms the inflammation with increased secretion of multiple cytokines and lymphokines (TNF- $\alpha$, IL-6, GM-CSF, IFN- $\gamma$, and IL8) [47]. This inflammatory syndrome can have various causes or risk factors such as genetics, infections, toxins, fetal restriction, and auto-immune diseases. ASD can be associated with a specific syndrome [48], such as Rett Syndrome, Fragile X syndrome, or 22q13 deletion. Rett syndrome is a neurodevelopmental disorder, which presents itself with neurologic defects. It is most frequently transmitted as an X-linked dominant disease linked to new methyl-CpG-binding protein gene mutations (MECP2). There is evidence of inflammation and dysregulation of the immune system early in life in this syndrome [45]. Fragile $X$ syndrome is associated with brain inflammation [49] with impaired immune response and over-reactive astrocytes. The 22q13 deletion is a genetic disorder caused by the deletion or disruption of segment 13 of the long arm of chromosome 22 [50]. There are multiple neurological features such as hypotonia, delayed speech, or autistic behavior. There are concomitant brain inflammation and auto-immune disease. Treatment with valproic acid is a well-recognized model of autism. Animals treated with prenatal valproic acid have reduced social interaction, decreased exploratory activity, and decreased prefrontal cortex mitochondrial complex activity. They show brain inflammation, oxidative stress, and increased blood-brain barrier permeability [51].

Inflammation has been described in every psychiatric disorder. Eugen Bleuler remarked in 1911: «The fragility of the blood vessels which appears in many schizophrenics, both acute and chronic, seems to indicate a real vascular pathology.» An association between inflammatory abnormalities and schizophrenia has been found repeatedly [52]. Van Kesteren analyzed the brain of the patients who died of schizophrenia and found a consistent brain inflammation report [53]. Similarly to ASD, there is in schizophrenia an inflammatory syndrome with increased secretion of interleukin (IL) 1-beta, IL-6, and transforming growth factor-beta [52]. Brain inflammation has been described in bipolar disease [54], depression [55], Nieman Pick [56], or anorexia nervosa [57].

Table 1. Every disease has an inflammatory component associated with malfunctioning mitochondria and increased secretion of lactic acid resulting from metabolic rewiring.

\begin{tabular}{ccccc}
\hline Organ & Disease & Inflammation & Mitochondrial Impairment & Lactic Acid Concentration \\
\hline \multirow{nyyyy}{*}{ Brain } & Autism & Yes & Yes [58] & Increased [59] \\
\cline { 2 - 5 } & Schizophrenia & Yes & Yes [58] & Increased [60] \\
\cline { 2 - 5 } & Meningitis & Yes & Yes [61] & Increased [60] \\
\cline { 2 - 5 } & Encephalitis & Yes [62] & Increased [63] \\
\cline { 2 - 5 } & Alzheimer & Yes [27] & Yes [64] & Stable under treatment [65] \\
\cline { 2 - 4 } & Parkinson & Yes & Yes [66] & Increased [67] \\
\hline
\end{tabular}


Table 1. Cont.

\begin{tabular}{|c|c|c|c|c|}
\hline Organ & Disease & Inflammation & Mitochondrial Impairment & Lactic Acid Concentration \\
\hline \multirow{3}{*}{ Cardio-vascular } & Cardiac infract & Yes: scarring & Yes [68] & Increased [69] \\
\hline & Cardiac failure & Yes & Yes [70] & Increased [69] \\
\hline & Stroke & Yes: scarring & Yes [71] & Increased [72] \\
\hline \multirow{4}{*}{ Bronchia alveolar } & Infection & Yes & Yes [73] & Not available \\
\hline & Fibrosis & Yes & Yes [74] & Increased [75] \\
\hline & Emphysema & Yes & Yes [76] & Increased [77] \\
\hline & Cancer & Yes & Yes [27] & Increased [27] \\
\hline \multirow{3}{*}{ Joint and muscular } & Arthritis & Yes & Yes [78] & Increased [77] \\
\hline & Myositis & Yes & Yes [79] & Not available \\
\hline & Sarcoma & Yes & Yes [27] & Increased [27] \\
\hline \multirow{3}{*}{ GI tract } & Hepatitis & Yes & Yes [80] & Increased [80] \\
\hline & Cirrhosis & Yes & Yes [81] & Increased [82] \\
\hline & ulcerative colitis & Yes & Yes [83] & Increased [84] \\
\hline \multirow{2}{*}{ Urinary tract } & Cystitis & Yes & Yes [85] & Increased [86] \\
\hline & Cancer & Yes & Yes [27] & Increased [27] \\
\hline \multirow{3}{*}{ Autoimmune disease } & Scleroderma & Yes & Yes [87] & Not available \\
\hline & Lupus & Yes & Yes [88] & Increased [89] \\
\hline & Sarcoidosis & Yes & Yes [90] & Increased [91] \\
\hline Down' syndrome & Diffuse & Yes & Yes [92] & Increased [93] \\
\hline Cystic fibrosis & Lung and GI tract & Yes & Yes [94] & Increased [95] \\
\hline Aging & Diffuse & Yes & Yes [27] & Increased [27] \\
\hline
\end{tabular}

\section{Inflammation Is Responsible for Metabolic Shifts}

Inflammation (a clinical feature) is closely related to hyperosmolarity (a physical characteristic) $[96,97]$. Animal models of inflammation demonstrate that, in an inflammatory fluid, whatever its cause, there is an increased protein content resulting in increased osmolarity (oncotic pressure). On the other hand, increased osmolarity, whatever its cause, results in inflammation [97]. Therefore, it is positive feedback control. Increased extracellular osmolarity increases cytokine synthesis and secretion and results in the proliferation and activation of immune cells [96]. Several reports claim hyperosmotic contents in the feces of patients suffering from inflammatory bowel disease $[96,98,99]$. GI tract lesions are caused by increased osmolarity.

An example is dextran sulfate sodium (DSS) induced colitis [100,101]. DSS is chemically inert. It is the hyperosmolarity caused by DSS, which causes colitis. When DSS is ingested at an osmolarity lower than $300 \mathrm{mosmol} / \mathrm{L}$, it displays no toxicity. At higher osmolarity, DSS induces dose-dependent colitis [102]. When the mouse is exposed to DSS, the chemical stays in the GI tract, but the distant lymph node is enlarged with a proliferation of the lymphocytes secondary to the extracellular space's widespread hyperosmolarity [102].

Hyperosmolarity has a dual effect. It can both stimulate the metabolism and induce apoptosis of cells. Hyperosmolarity induces the secretion of neurotransmitters [103]. In rodents, porcine and human loss of blood-brain barrier integrity by intra-arterial hyperosmotic mannitol has been shown to lead to EEG changes consistent with epileptic seizures, that is, spike/wave complexes interspersed with decreased EEG voltage [104]. Increased pressure exerted by mannitol decreased the amplitude of evoked field potentials and excitatory postsynaptic potentials [105]. 
There is an inflammatory component in every disease (see Table 2). There is a concomitant rewiring of the metabolic fluxes with an increase secretion of lactic acid. The increased pressure, such as inflammation, inhibits the mitochondria and induces lactic acid secretion [38]. The increased secretion of lactic acid, a stigma of the metabolic shift toward anabolism, feeds on the inflammatory cells and plays a part in the immune response, such as seen in all these diseases (see Table 2). This is in line with the concomitant finding of inflammation, mitochondrial impairment, and lactic acid secretion in most chronic diseases. Intraperitoneal injections in rats of hypertonic solutions result in the secretion of lactate by the brain cells [106].

Table 2. Energy metabolism and entropy in key biological processes.

\begin{tabular}{cc}
\hline Entropy Released as Biomass & Entropy Released as Heat \\
\hline Anabolism & Catabolism \\
\hline Lactic Fermentation & Respiration \\
\hline Anaerobic Glycolysis & Oxidative Phosphorylation \\
\hline Proliferation & Cell Differentiation \\
\hline Reduction & Oxidation \\
\hline Low ATP synthesis & High ATP synthesis \\
\hline Low water activity & High water activity \\
\hline
\end{tabular}

One way to interpret the effect of inflammation on the activation of the onset of latent diseases (e.g., cancer) is that inflammation interrupts the phenotypic suppression of initiated diseases by interrupting cellular parabiosis; cellular parabiosis is trans-cellular complementation of recessive cell defects by the healthy neighboring cells via intercellular molecular traffic through tube-like connections between cells [107]. Inflammation-induced matrix metalloproteinases are known to destroy such connections. Cellular parabiosis is key to tissue homeostasis that involves compensation for loss-of-function and averaging cell activities in tissues.

\section{Intracellular $\mathrm{pH}$ and the Consequence of the Metabolic Shifts}

There is a shift in mitochondrial activity in almost every disease resulting in increased lactate concentration [108]. In epithelial cells, the Warburg-effect results in cancer [26,108]. It is a longstanding debate whether cancer is one disease or a set of remarkably diverse diseases. For most researchers, various diseases with different prognoses, sites of origin, patterns of spread, and kinetics seem to be linked with cancer. However, despite this apparent complexity, there is underlying unity [96].

The Warburg effect is a bottleneck. The cells cannot burn the glucose because the pyruvate cannot de degraded in the Krebs' cycle. Evidence of the Warburg's central role comes when the researcher injects into cancer cells, with a micropipette, normal mitochondria. The growth will stop. These cells have become benign. The injection of the nuclei of cancer cells into normal cells does not increase growth. These cells can still burn glucose because the mitochondria are normal and do not form tumors [26].

The inhibition of the oxidative phosphorylation results in the activation of the anabolic pathway, such as the pentose phosphate pathway necessary for DNA and RNA synthesis $[20,109]$. The decreased mitochondrial activity has a second consequence: cytoplasm alkalinization because of decreased $\mathrm{CO}_{2}$ secretion [18]. Dysregulated $\mathrm{pH}$ is emerging as another hallmark of cancer because tumors show a 'reversed' $\mathrm{pH}$ gradient with a constitutively increased intracellular $\mathrm{pH}$ higher than the extracellular $\mathrm{pH}$ [110-113]. This gradient enables cancer progression by promoting proliferation, the evasion of apoptosis, metabolic adaptation, migration, and invasion [111,114-116]. In normal cells, the intracellular $\mathrm{pH}$ oscillates during the cell cycle between 6.8 and 7.3 [117]. The oscillation of the $\mathrm{pH}$ during the cell cycle matches the value of the decompaction of the histones, the RNA 
polymerase activation, the DNA polymerase activation, and the DNA compaction before mitosis. Carbon dioxide reacts with water to create carbonic acid. Cell transformation or enhanced cancer cell division and chemotherapy resistance are associated with a more alkaline $\mathrm{pH}[118,119]$.

The brain has the highest energy consumption of the body (around $20 \%$ of the body oxygen and $25 \%$ of the glucose) while representing 3\% of our body's mass. Neurons feed on lactate released by glial cells [27]. The increased secretion of lactate by glial cells results in increased uptake by neurons and intracellular acidosis [27]. To perform their normal physiological functions, cells must maintain the intracellular $\mathrm{pH}(\mathrm{pHi})$ within the physiological range. Intracellular enzyme activity, cytoskeleton component integration, and cellular growth and differentiation rates are strongly associated with the pHi [21]. Acidic intracellular $\mathrm{pHi}$ of the neuron results from the excessive secretion of lactic acid by the surrounding glial cells and results in apoptosis.

In cancer, mitochondrial impairment results in cell proliferation and tumor growth. In Alzheimer's disease, there is abnormal secretion of amyloid plaques, in Parkinson disease, there are intracellular deposits (Lewy bodies). In cancer, the alkaline $\mathrm{pH}$ results in cell proliferation. In neurodegenerative diseases, the acidic $\mathrm{pH}$ results in apoptosis [27].

Seen from a biologist's perspective, most metabolic pathways appear to be connected. However, from a physicist's standpoint, they all point towards an increased entropy flux within the body. Whatever the cause (i.e., genetic defect within the respiratory chain, inflammation, or toxicity of xenobiotics), they all converge toward a shift in the type of entropy that is produced. In other words, all these diseases have in common a decreased activity of the mitochondria. The synthesis of thermal photons is decreased, and there is a concomitant increase in biomass synthesis. This imbalance can be addressed in treating the primary cause (for example, a genetic defect in the electron transport chain) and/or by a medication targeting the mitochondria such as Methylene Blue. It is of utmost importance to better analyze the patients' metabolism to target therapy to restore the entropy imbalance.

\section{Conclusions: Handling the Complexity of Phenotypes in a Single Frame}

Up to now, most biological research has focused on isolated single biological reactions. Cell biology became a descriptive detailed molecular approach to "how" without knowing "what" and "why". It is a science lacking key concepts. Most biomedical research deals with "biomarkers," which are arbitrary downstream consequences of the cause of disease and the damage done by the disease. Acting upon such biomarkers cannot and does not cure diseases.

However, living organisms are energy-driven intricate integrated systems that should be described as open thermodynamic systems. When understood as physical systems, such organisms appear as open, non-equilibrium thermodynamic open systems exhibiting a hierarchical organization. Therefore, if such systems are to be understood, each component, such as a cell, organelle, or organ, should be subject to a thermodynamic description. To advance our understanding of the biological processes, they need to be evaluated and integrated into comprehensive fundamental theories based on physics principles.

The proposed entropy-centric paradigm for human diseases is placed in the relationship with basic aspects of cellular energy metabolism (Table 2).

Author Contributions: L.S. contributed to the conceptualization, data curation, formal analysis and writing (original draft). M.H., K.O.A., S.J.R. contributed to the conceptualization, data curation, resources, writing (original draft, and revised version). L.S. and M.R. contributed to the supervision, conceptualization, data curation, formal analysis, investigation, resources, software, writing (review \& editing). All authors have read and agreed to the published version of the manuscript.

Funding: This work was supported by the Fondation Guérir du Cancer.

Conflicts of Interest: The authors declare no conflict of interest. 


\section{References}

1. Henry, M.; Schwartz, L. Entropy export as the driving force of evolution. Substantia 2019, 3, 29-56. [CrossRef]

2. Schwartz, L.; Devin, A.; Bouillaud, F.; Henry, M. Entropy as the Driving Force of Pathogenesis: An Attempt of Diseases Classification Based on the Laws of Physics. Substantia 2020, 4. [CrossRef]

3. Henry, M. Thermodynamics of Life. Substantia 2020, 5, 43-71. [CrossRef]

4. Lehninger, A.L. Bioenergetics: The Molecular Basis of Biological Energy Transformations; Benjamin-Cummings Publishing Company: San Francisco, CA, USA, 1965.

5. Peregrín-Alvarez, J.M.; Sanford, C.; Parkinson, J. The conservation and evolutionary modularity of metabolism. Genome Biol. 2009, 10. [CrossRef]

6. Demetrius, L. Cellular systems as graphs. Bull. Math. Biophys. 1968, 30, 105-116. [CrossRef] [PubMed]

7. Schwartz, L.; da Veiga Moreira, J.; Jolicoeur, M. Physical forces modulate cell differentiation and proliferation processes. J. Cell. Mol. Med. 2018, 22, 738-745. [CrossRef]

8. McBride, H.M.; Neuspiel, M.; Wasiak, S. Mitochondria: More Than Just a Powerhouse. Curr. Biol. 2006, 16, R551-R560. [CrossRef]

9. Laflaquière, B.; Leclercq, G.; Choey, C.; Chen, J.; Peres, S.; Ito, C.; Jolicoeur, M. Identifying biomarkers of Wharton's Jelly mesenchymal stromal cells using a dynamic metabolic model: The cell passage effect. Metabolites 2018, 8, 18. [CrossRef] [PubMed]

10. John, C.S.J.; Ramalho-Santos, J.; Gray, H.L.; Petrosko, P.; Rawe, V.Y.; Navara, C.S.; Simerly, C.R.; Schatten, G.P. The expression of mitochondrial DNA transcription factors during early cardiomyocyte in vitro differentiation from human embryonic stemn cells. Cloning Stem Cells 2005, 7, 141-153. [CrossRef]

11. Mandal, S.; Lindgren, A.G.; Srivastava, A.S.; Clark, A.T.; Banerjee, U. Mitochondrial function controls proliferation and early differentiation potential of embryonic stem cells. Stem Cells 2011, 29, 486-495. [CrossRef] [PubMed]

12. Wanet, A.; Arnould, T.; Najimi, M.; Renard, P. Connecting Mitochondria, Metabolism, and Stem Cell Fate. Stem Cells Dev. 2015, 24, 1957-1971. [CrossRef]

13. Levenson, R.; Macara, I.G.; Smith, R.L.; Cantley, L.; Housman, D. Role of mitochondrial membrane potential in the regulation of murine erythroleukemia cell differentiation. Cell 1982, 28, 855-863. [CrossRef]

14. Buck, M.D.D.; O'Sullivan, D.; Klein Geltink, R.I.I.; Curtis, J.D.D.; Chang, C.H.; Sanin, D.E.E.; Qiu, J.; Kretz, O.; Braas, D.; van der Windt, G.J.J.W.; et al. Mitochondrial Dynamics Controls T Cell Fate through Metabolic Programming. Cell 2016, 166, 63-76. [CrossRef] [PubMed]

15. Pearce, E.L.; Poffenberger, M.C.; Chang, C.-H.; Jones, R.G. Fueling immunity: Insights into metabolism and lymphocyte function. Science 2013, 342, 1242454. [CrossRef] [PubMed]

16. Kasahara, A.; Scorrano, L. Mitochondria: From cell death executioners to regulators of cell differentiation. Trends Cell Biol. 2014, 24, 761-770. [CrossRef] [PubMed]

17. Zhang, Y.; Marsboom, G.; Toth, P.T.; Rehman, J. Mitochondrial Respiration Regulates Adipogenic Differentiation of Human Mesenchymal Stem Cells. PLoS ONE 2013, 8. [CrossRef] [PubMed]

18. Da Veiga Moreira, J.; Peres, S.; Steyaert, J.-M.M.; Bigan, E.; Paulevé, L.; Nogueira, M.L.; Schwartz, L. Cell cycle progression is regulated by intertwined redox oscillators. Theor. Biol. Med. Model. 2015, 12, 10. [CrossRef] [PubMed]

19. Da Veiga Moreira, J.; Hamraz, M.; Abolhassani, M.; Bigan, E.; Pérès, S.; Paulevé, L.; Nogueira, M.L.; Steyaert, J.-M.; Schwartz, L. The Redox Status of Cancer Cells Supports Mechanisms behind the Warburg Effect. Metabolites 2016, 6, 33. [CrossRef]

20. Alfarouk, K.O.; Ahmed, S.B.M.; Elliott, R.L.; Benoit, A.; Alqahtani, S.S.; Ibrahim, M.E.; Bashir, A.H.H.; Alhoufie, S.T.S.; Elhassan, G.O.; Wales, C.C.; et al. The Pentose Phosphate Pathway Dynamics in Cancer and Its Dependency on Intracellular pH. Metabolites 2020, 10, 285. [CrossRef]

21. Chiche, J.; Ilc, K.; Laferrière, J.; Trottier, E.; Dayan, F.; Mazure, N.M.; Brahimi-Horn, M.C.; Pouysségur, J. Hypoxia-inducible carbonic anhydrase IX and XII promote tumor cell growth by counteracting acidosis through the regulation of the intracellular pH. Cancer Res. 2009, 69, 358-368. [CrossRef]

22. McCully, K.K.; Fielding, R.A.; Evans, W.J.; Leigh, J.S.; Posner, J.D. Relationships between in vivo and in vitro measurements of metabolism in young and old human calf muscles. J. Appl. Physiol. 1993, 75, 813-819. [CrossRef]

23. Wertz, X.; Schoëvaërt, D.; Maitournam, H.; Chassignet, P.; Schwartz, L. The effect of hormones on bone growth is mediated through mechanical stress. Comptes Rendus-Biol. 2006, 329, 79-85. [CrossRef]

24. Zhang, P.C.; Keleshian, A.M.; Sachs, F. Voltage-induced membrane movement. Nature 2001, 413, 428-432. [CrossRef]

25. Ames, B.N.; Liu, J.; Atamna, H.; Hagen, T.M. Delaying the mitochondrial decay of aging in the brain. Clin. Neurosci. Res. 2003, 2, 331-338. [CrossRef]

26. Seyfried, T.N.; Flores, R.E.; Poff, A.M.; D'Agostino, D.P. Cancer as a metabolic disease: Implications for novel therapeutics. Carcinogenesis 2014, 35, 515-527. [CrossRef]

27. Schwartz, L.; Peres, S.; Jolicoeur, M.; da Veiga Moreira, J. Cancer and Alzheimer's disease: Intracellular pH scales the metabolic disorders. Biogerontology 2020, 21, 683-694. [CrossRef]

28. Fitzgerald, P.J. Norepinephrine release may play a critical role in the Warburg effect: An integrative model of tumorigenesis Neoplasma 2020. [CrossRef]

29. Altschule, M.D.; Henneman, D.H.; Holliday, P.; Goncz, R.M. Carbohydrate Metabolism in Brain Disease: VI. Lactate Metabolism after Infusion of Sodium d-Lactate in Manic-Depressive and Schizophrenic Psychoses. AMA Arch. Intern. Med. 1956, 98, 35-38. [CrossRef] [PubMed] 
30. Pitts, F.N.; McClure, J.N. Lactate metabolism in anxiety neurosis. N. Engl. J. Med. 1967, 277, 1329-1336. [CrossRef] [PubMed]

31. Liebowitz, M.R.; Hollander, E. Lactate-induced anxiety. Biol. Psychiatry 1989, 25, 669-670. [CrossRef]

32. Hollander, E.; Liebowitz, M.R.; Gorman, J.M.; Cohen, B.; Fyer, A.; Klein, D.F. Cortisol and Sodium Lactate-Induced Panic. Arch. Gen. Psychiatry 1989, 46, 135-140. [CrossRef]

33. Reiman, E.M.; Raichle, M.E.; Robins, E.; Mintun, M.A.; Fusselman, M.J.; Fox, P.T.; Price, J.L.; Hackman, K.A. Neuroanatomical Correlates of a Lactate-Induced Anxiety Attack. Arch. Gen. Psychiatry 1989, 46, 493-500. [CrossRef] [PubMed]

34. Mostafa, G.A.; El-Gamal, H.A.; El-Wakkad, A.S.E.; El-Shorbagy, O.E.; Hamza, M.M. Polyunsaturated fatty acids, carnitine and lactate as biological markers of brain energy in autistic children. Int. J. Child Neuropsychiatry 2005, 2, $179-188$.

35. Yehia, L.; Ni, Y.; Feng, F.; Seyfi, M.; Sadler, T.; Frazier, T.W.; Eng, C. Distinct Alterations in Tricarboxylic Acid Cycle Metabolites Associate with Cancer and Autism Phenotypes in Cowden Syndrome and Bannayan-Riley-Ruvalcaba Syndrome. Am. J. Hum. Genet. 2019, 105, 813-821. [CrossRef] [PubMed]

36. Goh, S.; Dong, Z.; Zhang, Y.; DiMauro, S.; Peterson, B.S. Mitochondrial dysfunction as a neurobiological subtype of autism spectrum disorder: Evidence from brain imaging. JAMA Psychiatry 2014, 71, 665-671. [CrossRef] [PubMed]

37. Regenold, W.T.; Phatak, P.; Marano, C.M.; Sassan, A.; Conley, R.R.; Kling, M.A. Elevated Cerebrospinal Fluid Lactate Concentrations in Patients with Bipolar Disorder and Schizophrenia: Implications for the Mitochondrial Dysfunction Hypothesis. Biol. Psychiatry 2009, 65, 489-494. [CrossRef]

38. Hamraz, M.; Abolhassani, R.; Andriamihaja, M.; Ransy, C.; Lenoir, V.; Schwartz, L.; Bouillaud, F. Hypertonic external medium represses cellular respiration and promotes Warburg/Crabtree effect. FASEB J. 2020, 34, 222-236. [CrossRef]

39. Spilioti, M.; Evangeliou, A.E.; Tramma, D.; Theodoridou, Z.; Metaxas, S.; Michailidi, E.; Bonti, E.; Frysira, H.; Haidopoulou, A.; Asprangathou, D.; et al. Evidence for treatable inborn errors of metabolism cohort of 187 greek patients with autism spectrum (ASD). Front. Hum. Neurosci. 2013, 7. [CrossRef]

40. Maurer, I.; Zierz, S.; Möller, H.J. Evidence for a mitochondrial oxidative phosphorylation defect in brains from patients with schizophrenia. Schizophr. Res. 2001, 48, 125-136. [CrossRef]

41. Xu, Z.; Guo, X.; Yang, Y.; Tucker, D.; Lu, Y.; Xin, N.; Zhang, G.; Yang, L.; Li, J.; Du, X.; et al. Low-Level Laser Irradiation Improves Depression-Like Behaviors in Mice. Mol. Neurobiol. 2017, 54, 4551-4559. [CrossRef]

42. Sinning, A.; Hübner, C.A. Minireview: PH and synaptic transmission. FEBS Lett. 2013, 587, 1923-1928. [CrossRef] [PubMed]

43. Staub, F.; Mackert, B.; Kempski, O.; Peters, J.; Baethmann, A. Swelling and death of neuronal cells by lactic acid. J. Neurol. Sci. 1993, 119, 79-84. [CrossRef]

44. Herpertz-Dahlmann, B.; Seitz, J.; Baines, J. Food matters: How the microbiome and gut-brain interaction might impact the development and course of anorexia nervosa. Eur. Child Adolesc. Psychiatry 2017, 26, 1031-1041. [CrossRef]

45. Theoharides, T.C.; Athanassiou, M.; Panagiotidou, S.; Doyle, R. Dysregulated brain immunity and neurotrophin signaling in Rett syndrome and autism spectrum disorders. J. Neuroimmunol. 2015, 279, 33-38. [CrossRef]

46. Theoharides, T.C.; Kavalioti, M.; Tsilioni, I. Mast cells, stress, fear and autism spectrum disorder. Int. J. Mol. Sci. $2019,20,3611$. [CrossRef]

47. Li, X.; Chauhan, A.; Sheikh, A.M.; Patil, S.; Chauhan, V.; Li, X.M.; Ji, L.; Brown, T.; Malik, M. Elevated immune response in the brain of autistic patients. J. Neuroimmunol. 2009, 207, 111-116. [CrossRef]

48. Freitas, B.C.; Mei, A.; Mendes, A.P.D.; Beltrão-Braga, P.C.B.; Marchetto, M.C. Modeling inflammation in autism spectrum disorders using stem cells. Front. Pediatr. 2018, 6, 394. [CrossRef] [PubMed]

49. Belmonte, M.K.; Bourgeron, T. Fragile X syndrome and autism at the intersection of genetic and neural networks. Nat. Neurosci. 2006, 9, 1221-1225. [CrossRef] [PubMed]

50. Kiyota, K.; Yoshiura, K.-i.; Houbara, R.; Miyahara, H.; Korematsu, S.; Ihara, K. Auto-immune disorders in a child with PIK3CD variant and 22q13 deletion. Eur. J. Med. Genet. 2018, 61, 631-633. [CrossRef] [PubMed]

51. Kumar, H.; Sharma, B. Minocycline ameliorates prenatal valproic acid induced autistic behaviour, biochemistry and blood brain barrier impairments in rats. Brain Res. 2016, 1630, 83-97. [CrossRef] [PubMed]

52. Saetre, P.; Emilsson, L.; Axelsson, E.; Kreuger, J.; Lindholm, E.; Jazin, E. Inflammation-related genes up-regulated in schizophrenia brains. BMC Psychiatry 2007, 7. [CrossRef] [PubMed]

53. Van Kesteren, C.F.M.G.; Gremmels, H.; De Witte, L.D.; Hol, E.M.; Van Gool, A.R.; Falkai, P.G.; Kahn, R.S.; Sommer, I.E.C. Immune involvement in the pathogenesis of schizophrenia: A meta-analysis on postmortem brain studies. Transl. Psychiatry 2017, 7, e1075. [CrossRef]

54. Giridharan, V.V.; Sayana, P.; Pinjari, O.F.; Ahmad, N.; da Rosa, M.I.; Quevedo, J.; Barichello, T. Postmortem evidence of brain inflammatory markers in bipolar disorder: A systematic review. Mol. Psychiatry 2020, 25, 94-113. [CrossRef]

55. Dantzer, R.; O'Connor, J.C.; Freund, G.G.; Johnson, R.W.; Kelley, K.W. From inflammation to sickness and depression: When the immune system subjugates the brain. Nat. Rev. Neurosci. 2008, 9, 46-56. [CrossRef] [PubMed]

56. Platt, N.; Speak, A.O.; Colaco, A.; Gray, J.; Smith, D.A.; Williams, I.M.; Wallom, K.L.; Platt, F.M. Immune dysfunction in Niemann-Pick disease type C. J. Neurochem. 2016, 136, 74-80. [CrossRef] [PubMed]

57. Haznedar, M. Volumetric Analysis and Three-Dimensional Glucose Metabolic Mapping of the Striatum and Thalamus in Patients With Autism Spectrum Disorders. Am. J. Psychiatry 2006, 163, 1252. [CrossRef]

58. Zimmerman, A.W.; Jyonouchi, H.; Comi, A.M.; Connors, S.L.; Milstien, S.; Varsou, A.; Heyes, M.P. Cerebrospinal fluid and serum markers of inflammation in autism. Pediatr. Neurol. 2005, 33, 195-201. [CrossRef] 
59. Vallée, A.; Vallée, J.N. Warburg effect hypothesis in autism Spectrum disorders. Mol. Brain 2018, 11, 1-7. [CrossRef]

60. Looney, J.M.; Childs, H.M. The lactic acid and glutathione content of the blood of schizophrenic patients. J. Clin. Investig. 1934, 13, 963-968. [CrossRef]

61. Nau, R.; Brück, W. Neuronal injury in bacterial meningitis: Mechanisms and implications for therapy. Trends Neurosci. 2002, 25, 38-45. [CrossRef]

62. Myhill, S. Diagnosis and Treatment of Chronic Fatigue Syndrome and Myalgic Encephalitis: It's Mitochondria, Not Hypochondria; Chelsea Green Publishing: White River Junction, VT, USA, 2018.

63. Paulson, O.B.; Brodersen, P.; Hansen, E.L.; Kristensen, H.S. Regional cerebral blood flow, cerebral metabolic rate of oxygen, and cerebrospinal fluid acid-base variables in patients with acute meningitis and with acute encephalitis. Acta Med. Scand. 1974, 196, 191-198. [CrossRef]

64. Kösel, S.; Hofhaus, G.; Maassen, A.; Vieregge, P.; Graeber, M.B. Role of mitochondria in Parkinson disease. Biol. Chem. 1999, 380, 865-870. [CrossRef] [PubMed]

65. Yamamoto, M.; Ujike, H.; Wada, K.; Tsuji, T. Cerebrospinal fluid lactate and pyruvate concentrations in patients with Parkinson's disease and mitochondrial encephalomyopathy, lactic acidosis, and stroke-like episodes (MELAS). J. Neurol. Neurosurg. Psychiatry 1997, 62. [CrossRef]

66. Quintanilla, R.A.; Jin, Y.N.; Von Bernhardi, R.; Johnson, G.V. Mitochondrial permeability transition pore induces mitochondria injury in Huntington disease. Mol. Neurodegener. 2013, 8, 1-19. [CrossRef]

67. Koroshetz, W.J.; Jenkins, B.G.; Rosen, B.R.; Flint Beal, M. Energy metabolism defects in Huntington's disease and effects of coenzyme Q10. Ann. Neurol. 1997, 41, 160-165. [CrossRef]

68. Calva, E.; Mújica, A.; Núñez, R.; Aoki, K.; Bisteni, A.; Sodi-Pallares, D. Mitochondrial biochemical changes and glucose-KClinsulin solution in cardiac infarct. Am. J. Physiol. 1966, 211, 71-76. [CrossRef]

69. Henning, R.J.; Weil, M.H.; Weiner, F. Blood lactate as a prognostic indicator of survival in patients with acute myocardial infarction. Circ. Shock 1982, 9, 307-315.

70. Marin-Garcia, J.; Goldenthal, M.J.; Moe, G.W. Mitochondrial pathology in cardiac failure. Cardiovasc. Res. 2001, 49, 17-26. [CrossRef]

71. Sims, N.R.; Muyderman, H. Mitochondria, oxidative metabolism and cell death in stroke. Biochim. Biophys. Acta-Mol. Basis Dis. 2010, 1802, 80-91. [CrossRef]

72. Bruhn, H.; Frahm, J.; Gyngell, M.L.; Merboldt, K.D.; Hänicke, W.; Sauter, R. Cerebral metabolism in man after acute stroke: New observations using localized proton NMR spectroscopy. Magn. Reson. Med. 1989, 9, 126-131. [CrossRef]

73. Yamada, H.; Chounan, R.; Higashi, Y.; Kurihara, N.; Kido, H. Mitochondrial targeting sequence of the influenza A virus PB1-F2 protein and its function in mitochondria. FEBS Lett. 2004, 578, 331-336. [CrossRef] [PubMed]

74. Yu, G.; Tzouvelekis, A.; Wang, R.; Herazo-Maya, J.D.; Ibarra, G.H.; Srivastava, A.; De Castro, J.P.W.; Deiuliis, G.; Ahangari, F.; Woolard, T.; et al. Thyroid hormone inhibits lung fibrosis in mice by improving epithelial mitochondrial function. Nat. Med. 2018, 24, 39-49. [CrossRef]

75. Maher, T.M. Aerobic glycolysis and the warburg effect an unexplored realm in the search for fibrosis therapies? Am. J. Respir. Crit. Care Med. 2015, 192, 1407-1409. [CrossRef] [PubMed]

76. Li, F.; Xu, M.; Wang, M.; Wang, L.; Wang, H.; Zhang, H.; Chen, Y.; Gong, J.; Zhang, J.; Adcock, I.M.; et al. Roles of mitochondrial ROS and NLRP3 inflammasome in multiple ozone-induced lung inflammation and emphysema. Respir. Res. 2018, 19, 230. [CrossRef] [PubMed]

77. Morrison, W.L.; Gibson, J.N.A.; Scrimgeour, C.; Rennie, M.J. Muscle wasting in emphysema. Clin. Sci. 1988, 75, 415-420. [CrossRef]

78. Mitsunaga, S.; Hosomichi, K.; Okudaira, Y.; Nakaoka, H.; Suzuki, Y.; Kuwana, M.; Sato, S.; Kaneko, Y.; Homma, Y.; Oka, A.; et al. Aggregation of rare/low-frequency variants of the mitochondria respiratory chain-related proteins in rheumatoid arthritis patients. J. Hum. Genet. 2015, 60, 449-454. [CrossRef]

79. Oldfors, A.; Moslemi, A.R.; Fyhr, I.M.; Holme, E.; Larsson, N.G.; Lindberg, C. Mitochondrial DNA deletions in muscle fibers in inclusion body myositis. J. Neuropathol. Exp. Neurol. 1995, 54, 581-587. [CrossRef]

80. Gane, E.J.; Weilert, F.; Orr, D.W.; Keogh, G.F.; Gibson, M.; Lockhart, M.M.; Frampton, C.M.; Taylor, K.M.; Smith, R.A.J.; Murphy, M.P. The mitochondria-targeted anti-oxidant mitoquinone decreases liver damage in a phase II study of hepatitis C patients. Liver Int. 2010, 30, 1019-1026. [CrossRef]

81. Krähenbühl, S.; Stucki, J.; Reichen, J. Reduced activity of the electron transport chain in liver mitochondria isolated from rats with secondary biliary cirrhosis. Hepatology 1992, 15, 1160-1166. [CrossRef]

82. Kershenobich, D.; García-Tsao, G.; Saldana, S.A.; Rojkind, M. Relationship between blood lactic acid and serum proline in alcoholic liver cirrhosis. Gastroenterology 1981, 80, 1012-1015. [CrossRef]

83. Sifroni, K.G.; Damiani, C.R.; Stoffel, C.; Cardoso, M.R.; Ferreira, G.K.; Jeremias, I.C.; Rezin, G.T.; Scaini, G.; Schuck, P.F.; Dal-Pizzol, F.; et al. Mitochondrial respiratory chain in the colonic mucosal of patients with ulcerative colitis. Mol. Cell. Biochem. 2010, 342, 111-115. [CrossRef] [PubMed]

84. Vernia, P.; Caprilli, R.; Latella, G.; Barbetti, F.; Magliocca, F.M.; Cittadini, M. Fecal Lactate and Ulcerative Colitis. Gastroenterology 1988, 95, 1564-1568. [CrossRef] 
85. Liu, K.M.; Chuang, S.M.; Long, C.Y.; Lee, Y.L.; Wang, C.C.; Lu, M.C.; Lin, R.J.; Lu, J.H.; Jang, M.Y.; Wu, W.J.; et al. Ketamineinduced ulcerative cystitis and bladder apoptosis involve oxidative stress mediated by mitochondria and the endoplasmic reticulum. Am. J. Physiol.-Ren. Physiol. 2015, 309, 318-331. [CrossRef] [PubMed]

86. Brook, I.; Belman, A.B.; Controni, G. Lactic acid in urine of children with lower and upper urinary tract infection and renal obstruction. Am. J. Clin. Pathol. 1981, 75, 110-113. [CrossRef]

87. Reimer, G. Autoantibodies against nuclear, nucleolar, and mitochondrial antigens in systemic sclerosis (scleroderma). Rheum. Dis. Clin. North Am. 1990, 16, 169-183.

88. Yang, S.-K.; Zhang, H.-R.; Shi, S.-P.; Zhu, Y.-Q.; Song, N.; Dai, Q.; Zhang, W.; Gui, M.; Zhang, H. The Role of Mitochondria in Systemic Lupus Erythematosus: A Glimpse of Various Pathogenetic Mechanisms. Curr. Med. Chem. 2018, 27, 3346-3361. [CrossRef]

89. McCaffrey, L.M.; Petelin, A.; Cunha, B.A. Systemic lupus erythematosus (SLE) cerebritis versus Listeria monocytogenes meningoencephalitis in a patient with systemic lupus erythematosus on chronic corticosteroid therapy: The diagnostic importance of cerebrospinal fluid (CSF) of lactic acid levels. Hear. Lung J. Acute Crit. Care 2012, 41, 394-397. [CrossRef]

90. Daniil, Z.; Kotsiou, O.S.; Grammatikopoulos, A.; Peletidou, S.; Gkika, H.; Malli, F.; Antoniou, K.; Vasarmidi, E.; Mamuris, Z.; Gourgoulianis, K.; et al. Detection of mitochondrial transfer RNA (mt-tRNA) gene mutations in patients with idiopathic pulmonary fibrosis and sarcoidosis. Mitochondrion 2018, 43, 43-52. [CrossRef]

91. Talreja, J.; Talwar, H.; Bauerfeld, C.; Grossman, L.I.; Zhang, K.; Tranchida, P.; Samavati, L. Hif- $1 \alpha$ regulates il-1ßand il-17 in sarcoidosis. Elife 2019, 8. [CrossRef]

92. Busciglio, J.; Pelsman, A.; Wong, C.; Pigino, G.; Yuan, M.; Mori, H.; Yankner, B.A. Altered metabolism of the amyloid $\beta$ precursor protein is associated with mitochondrial dysfunction in Down's syndrome. Neuron 2002, 33, 677-688. [CrossRef]

93. Gross, T.J.; Doran, E.; Cheema, A.K.; Head, E.; Lott, I.T.; Mapstone, M. Plasma metabolites related to cellular energy metabolism are altered in adults with Down syndrome and Alzheimer's disease. Dev. Neurobiol. 2019, 79, 622-638. [CrossRef]

94. Shapiro, B.L. Evidence for a mitochondrial lesion in cystic fibrosis. Life Sci. 1989, 44, 1327-1334. [CrossRef]

95. Emrich, H.M.; Stoll, E.; Friolet, B.; Colombo, J.P.; Richterich, R.; Rossi, E. Sweat composition in relation to rate of sweating in patients with cystic fibrosis of the pancreas. Pediatr. Res. 1968, 2, 464-478. [CrossRef] [PubMed]

96. Abolhassani, M.; Wertz, X.; Pooya, M.; Chaumet-Riffaud, P.; Guais, A.; Schwartz, L. Hyperosmolarity causes inflammation through the methylation of protein phosphatase 2A. Inflamm. Res. 2008, 57, 419-429. [CrossRef]

97. Schwartz, L.; Israël, M.; Philippe, I. Inflammation and carcinogenesis: A change in the metabolic process. In Cancer Microenvironment and Therapeutic Implications; Baronzio, G., Fiorentini, G., Cogle, C.R., Eds.; Springer: Dordrecht, The Netherlands, 2009; pp. 3-18. ISBN 978-1-4020-9575-7.

98. Schwartz, L.; Guais, A.; Pooya, M.; Abolhassani, M. Is inflammation a consequence of extracellular hyperosmolarity? J. Inflamm. (Lond.) 2009, 6, 21. [CrossRef]

99. Németh, Z.H.; Deitch, E.A.; Szabó, C.; Haskó, G. Hyperosmotic stress induces nuclear factor-kB activation and interleukin-8 production in human intestinal epithelial cells. Am. J. Pathol. 2002, 161, 987-996. [CrossRef]

100. Chassaing, B.; Aitken, J.D.; Malleshappa, M.; Vijay-Kumar, M. Dextran sulfate sodium (DSS)-induced colitis in mice. Curr. Protoc. Immunol. 2014, 104. [CrossRef]

101. Guo, H.X.; Ye, N.; Yan, P.; Qiu, M.Y.; Zhang, J.; Shen, Z.G.; He, H.Y.; Tian, Z.Q.; Li, H.L.; Li, J.T. Sodium chloride exacerbates dextran sulfate sodium-induced colitis by tuning proinflammatory and antiinflammatory lamina propria mononuclear cells through p38/MAPK pathway in mice. World J. Gastroenterol. 2018, 24, 1779-1794. [CrossRef]

102. Schwartz, L.; Abolhassani, M.; Pooya, M.; Steyaert, J.-M.; Wertz, X.; Israël, M.; Guais, A.; Chaumet-Riffaud, P. Hyperosmotic stress contributes to mouse colonic inflammation through the methylation of protein phosphatase 2A. Am. J. Physiol. Gastrointest. Liver Physiol. 2008, 295, G934-G941. [CrossRef]

103. Chan, P.H.; Wong, Y.P.; Fishman, R.A. Hyperosmolality-induced GABA release from rat brain slices: Studies of calcium dependency and sources of release. J. Neurochem. 1978, 30, 1363-1368. [CrossRef]

104. Marchi, N.; Tierney, W.; Alexopoulos, A.V.; Puvenna, V.; Granata, T.; Janigro, D. The Etiological Role of Blood-Brain Barrier Dysfunction in Seizure Disorders. Cardiovasc. Psychiatry Neurol. 2011. [CrossRef]

105. Rosen, A.S.; Andrew, R.D. Osmotic effects upon excitability in rat neocortical slices. Neuroscience 1990, 38, 579-590. [CrossRef]

106. Chan, P.H.; Pollack, E.; Fishman, R.A. Differential effects of hypertonic mannitol and glycerol on rat brain metabolism and amino acids. Brain Res. 1981, 225, 143-153. [CrossRef]

107. Radman, M. Cellular parabiosis and the latency of age-related diseases. Open Biol. 2019, 9, 180250. [CrossRef]

108. Alfarouk, K.O.; Verduzco, D.; Rauch, C.; Muddathir, A.K.; Bashir, A.H.H.; Elhassan, G.O.; Ibrahim, M.E.; Orozco, P.J.D.; Cardone, R.A.; Reshkin, S.J.; et al. Glycolysis, tumor metabolism, cancer growth and dissemination. A new pH-based etiopathogenic perspective and therapeutic approach to an old cancer question. Oncoscience 2014, 1, 777-802. [CrossRef]

109. Ortega, A.D.; Sánchez-Aragó, M.; Giner-Sánchez, D.; Sánchez-Cenizo, L.; Willers, I.; Cuezva, J.M. Glucose avidity of carcinomas. Cancer Lett. 2009, 276, 125-135. [CrossRef]

110. Alfarouk, K.O.; Ahmed, S.B.M.; Ahmed, A.; Elliott, R.L.; Ibrahim, M.E.; Ali, H.S.; Wales, C.C.; Nourwali, I.; Aljarbou, A.N.; Bashir, A.H.H.; et al. The interplay of dysregulated ph and electrolyte imbalance in cancer. Cancers 2020, 12, 898. [CrossRef]

111. Alfarouk, K.O.; Muddathir, A.K.; Shayoub, M.E.A. Tumor acidity as evolutionary spite. Cancers 2011, 3, 408. [CrossRef] 
112. Schwartz, L.; Seyfried, T.; Alfarouk, K.O.; Da Veiga Moreira, J.; Fais, S. Out of Warburg effect: An effective cancer treatment targeting the tumor specific metabolism and dysregulated pH. Semin. Cancer Biol. 2017, 43, 134-138. [CrossRef]

113. Schwartz, L.; Supuran, C.T.; Alfarouk, K.O. The Warburg effect and the Hallmarks of Cancer. Anticancer. Agents Med. Chem. 2017, 17, 164-170. [CrossRef]

114. Gatenby, R.A.; Gillies, R.J. A microenvironmental model of carcinogenesis. Nat. Rev. Cancer 2008, 8, 56-61. [CrossRef]

115. Webb, B.A.; Chimenti, M.; Jacobson, M.P.; Barber, D.L. Dysregulated pH: A perfect storm for cancer progression. Nat. Rev. Cancer 2011, 11, 671-677. [CrossRef]

116. Lee, C.H.; Cragoe, E.J.; Edwards, A.M. Control of hepatocyte DNA synthesis by intracellular $\mathrm{pH}$ and its role in the action of tumor promoters. J. Cell. Physiol. 2003, 195, 61-69. [CrossRef]

117. Karagiannis, J.; Young, P.G. Intracellular $\mathrm{pH}$ homeostasis during cell-cycle progression and growth state transition in Schizosaccharomyces pombe. J. Cell Sci. 2001, 114, 2929-2941.

118. Alfarouk, K.O.; Stock, C.-M.; Taylor, S.; Walsh, M.; Muddathir, A.K.; Verduzco, D.; Bashir, A.H.H.; Mohammed, O.Y.; Elhassan, G.O.; Harguindey, S.; et al. Resistance to cancer chemotherapy: Failure in drug response from ADME to P-gp. Cancer Cell Int. 2015, 15, 71. [CrossRef]

119. Alfarouk, K.O. Tumor metabolism, cancer cell transporters, and microenvironmental resistance. J. Enzym. Inhib. Med. Chem. 2016, 6366, 1-8. [CrossRef] 